\title{
Modeling N/S ratio and temperature influences on simultaneous biological denitrification and sulfide oxidation
}

\author{
Michal Sposob $^{1} \quad$ Rune Bakke $^{1} \quad$ Carlos Dinamarca $^{1}$ \\ ${ }^{1}$ Department of Process, Energy and Environmental Technology, University College of Southeast Norway, Norway \\ michal.sposob@usn.no
}

\begin{abstract}
A model describing the simultaneous removal of $\mathrm{NO}_{3}{ }^{-}$and $\mathrm{HS}^{-}$by microorganisms is presented here. The oxidation of HS- (electron donor) can be controlled by the appropriate dosage of $\mathrm{NO}_{3}^{-}$. The developed model, which includes variable process stoichiometry, attempts to predict the distribution of sulfur oxidation products. Stoichiometric coefficients are based on a 150 days experimental study of temperature $\left(25-10{ }^{\circ} \mathrm{C}\right)$ and $\mathrm{N} / \mathrm{S}$ ratio (0.35-1.30) effects. The model can be used as a prediction tool for autotrophic denitrification with HSElemental sulfur production is included in the mathematical model, however, its accumulation and release (as $\mathrm{SO}_{4}{ }^{2-}$ ) with increasing feed $\mathrm{N} / \mathrm{S}$ ratio (e.g. leading to higher effluent than feed total sulfur mass at $\mathrm{N} / \mathrm{S}=1.30$ ) is not simulated. A conceptual model to account for biological accumulation and release of elemental sulfur is proposed here.
\end{abstract}

Keywords: autotrophic denitrification, elemental sulfur production, mathematical modeling, sulfate production

\section{Introduction}

The presence of sulfide $\left(\mathrm{H}_{2} \mathrm{~S}\right)$ in wastewaters is an important issue concerning wastewater networks and treatment plants maintenance due to its corrosive properties (Ma et al., 2000). Low concentrations of $\mathrm{H}_{2} \mathrm{~S}$ (lower than $10 \mathrm{mg} / \mathrm{L}$ ) are present in domestic wastewaters (Pikaar et al., 2011). The exposure to $\mathrm{H}_{2} \mathrm{~S}$ in gaseous form is toxic to human even at low concentrations and can paralyze the olfactory nerves and lead to death (Reiffenstein et al., 1992).

Biological wastewater treatment plants used to remove carbon, nitrogen and phosphorus can be inhibited by extensive presence of $\mathrm{H}_{2} \mathrm{~S}$ (Chen et al., 2008; Jin et al., 2013; Joye and Hollibaugh, 1995). It has been reported that anaerobic digestion process can be inhibited at concentrations from $50 \mathrm{mg} \mathrm{H}_{2} \mathrm{~S} / \mathrm{L}$ (Chen et al., 2008). $\mathrm{H}_{2} \mathrm{~S}$ presence can vary due to the high complexity of the sulfur (S) cycle and its partial overlapping with cycles of other elements (i.e. C, Fe, $\mathrm{Hg}, \mathrm{N}$ and Se). Knowledge of these cycles can be used for biochemical $\mathrm{H}_{2} \mathrm{~S}$ control and $\mathrm{S}$ removal.

Physicochemical $\mathrm{H}_{2} \mathrm{~S}$ removal is often used for $\mathrm{H}_{2} \mathrm{~S}$ removal (desulfurization) in industrial scale. The Claus process, where elemental sulfur $\left(\mathrm{S}^{0}\right)$ is recovered from $\mathrm{H}_{2} \mathrm{~S}$-containing gases under high temperature and oxygen $\left(\mathrm{O}_{2}\right)$ supply, is the most common method. Biological treatment, utilizing the unique properties of microorganisms, is gaining attention due to the environmental and economic advantages. Biological $\mathrm{H}_{2} \mathrm{~S}$ removal from wastewaters utilizes the ionic forms $\mathrm{HS}^{-}$and/or $\mathrm{S}^{2-}$ (depending on $\mathrm{pH}$ ) as the electron donor, while usually nitrate $\left(\mathrm{NO}_{3}{ }^{-}\right)$, nitrite $\left(\mathrm{NO}_{2}{ }^{-}\right)$and $\mathrm{O}_{2}$ are electron acceptor sources. The usage of these electron acceptors is not mutually exclusive, so they can be used together and separately. Addition of more than one electron acceptor can be applied to enhance the $\mathrm{H}_{2} \mathrm{~S}$ removal (Wang et al., 2015). Due to advantages such as a higher solubility of $\mathrm{NO}_{3}^{-}$than $\mathrm{O}_{2}, \mathrm{NO}_{3}^{-}$usage is studied here. It is argued that the continuous flow expanded granular sludge bed (EGSB) bioreactor is the most efficient design for biological desulfurization (Cai et al., 2010). Data from a previous EGSB study (Sposob et al., 2017a; 2017b) are used here.

The oxidation of HS can be controlled by the ratio between electron acceptor and electron donor to influence the relative amounts of the oxidation products: $\mathrm{S}^{0}$ and sulfate $\left(\mathrm{SO}_{4}{ }^{2-}\right)$. Extensive experimental and theoretical studies on the appropriate conditions for simultaneous $\mathrm{N}$ and $\mathrm{S}$ removal, i.e. $\mathrm{C} / \mathrm{N} / \mathrm{S}$ ratio, $\mathrm{pH}$, load and temperature, have been conducted (Di Capua et al., 2017; Guo et al., 2016; Huang et al., 2016; Mahmood et al., 2007; Montalvo et al., 2016; Reyes-Avila et al., 2004; Sposob et al., 2017a). Modeling can facilitate further understanding and optimization of simultaneous biological $\mathrm{NO}_{3}{ }^{-}$and $\mathrm{HS}^{-}$removal. So far, a few models based on artificial neural networks (Wang et al., 2009) and kinetic approach (Wang et al., 2010; Xu et al., 2016, 2014) have been developed. The kinetic models are based on batch experiments where only the initial phase of the process is accounted for. Fixed stoichiometry based on assumed chemical reactions or based on calculated and/or experimentally obtained yield values also limits published models, since the ratio between electron acceptor and electron donor can completely alter the output (Cai et al., 2008; Sposob et al., 2017b). The models describing simultaneous removal of $\mathrm{NO}_{3}{ }^{-}$ and HS- should take into account the fact that effluents from this kind of treatment can contain several products 
especially at low N/S ratios. This is challenging since it has been observed in long-term experiment that $\mathrm{SO}_{4}^{2-}$ and $\mathrm{S}^{0}$ were produced at the same time at feed $\mathrm{N} / \mathrm{S}$ ratio that theoretically should lead to $\mathrm{S}^{0}$ production only (Sposob et al., 2017a; Tan et al., 2016). It has also been observed that temperature has an impact on effluent sulfur components at constant N/S ratio (Sposob et al., 2017a). Thus, the need for the modeling including multicomponent effluent characteristic is required, especially in cases where lower N/S ratios are modeled.

The objective of this study is to develop a model for simultaneous removal of $\mathrm{NO}_{3}{ }^{-}$and $\mathrm{HS}^{-}$at different $\mathrm{N} / \mathrm{S}$ ratios and temperatures, which can be used to predict the distribution of produced sulfur components.

\section{Methods and model development}

\subsection{Experimental design}

The experimental trial was performed in a $0.5 \mathrm{~L}$ laboratory-scale EGSB reactor continuously fed by synthetic wastewater over 150 days. The feeding parameters are given in Table 1.

Table 1. Feeding parameters.

\begin{tabular}{|c|c|c|c|c|}
\hline Time (d) & $\begin{array}{l}\text { Temperature } \\
\left({ }^{\circ} \mathrm{C}\right)\end{array}$ & $\begin{array}{l}N / S \\
\text { ratio }\end{array}$ & $\begin{array}{l}\mathrm{NO}_{3}^{-} \\
(\mathrm{mM} / \mathrm{L})\end{array}$ & $\begin{array}{l}H S^{-} \\
(m M / L)\end{array}$ \\
\hline $1-25$ & 25 & \multirow{4}{*}{0.35} & \multirow{4}{*}{1.08} & \multirow{7}{*}{3.12} \\
\hline $26-57$ & 20 & & & \\
\hline $58-90$ & 15 & & & \\
\hline $91-120$ & \multirow{4}{*}{10} & & & \\
\hline $121-134$ & & 0.40 & 1.25 & \\
\hline $135-142$ & & 0.60 & 1.87 & \\
\hline $143-150$ & & 1.30 & 4.05 & \\
\hline
\end{tabular}

Synthetic wastewater was supplied from two feed tanks (separate for electron acceptor and donor) to avoid contamination and possible reactions in feeding tank. In addition to electron acceptor and donor sources, vitamins, buffer, macro- and microelements were supplied as described in Sposob et al. (2017a), where the more detailed description of experiment is given.

\subsection{Stoichiometry}

The model is developed and evaluated based on the stoichiometry derived by Kleerebezem and Mendez, (2002) and data from continuous flow expanded granular sludge bed (EGSB) experiments (Sposob et al., $2017 \mathrm{a} ; 2017 \mathrm{~b})$. The collected data consists information about concentrations of accumulated elemental sulfur $\left(\mathrm{S}^{0}{ }_{\text {acc }}\right)$, nitrate $\left(\mathrm{NO}_{3}{ }^{-}\right)$, sulfate $\left(\mathrm{SO}_{4}{ }^{2-}\right)$, sulfide $\left(\mathrm{HS}^{-}\right)$and suspended elemental sulfur $\left(\mathrm{S}^{0}{ }_{\mathrm{ss}}\right)$ measured as thiosulfate $\left(\mathrm{S}_{2} \mathrm{O}_{3}{ }^{2-}\right)$. Accumulated sulfur $\left(\mathrm{S}^{0}{ }_{\text {acc }}\right)$ was calculated based on the difference between influent $\mathrm{HS}^{-}$ concentration and effluent concentrations of $\mathrm{HS}^{-}, \mathrm{SO}_{4}{ }^{2-}$ and $\mathrm{S}^{0}{ }_{\text {ss}}$, according to Eq. 1 (Sposob et al., 2017a).

$$
\mathrm{S}^{0}{ }_{\text {acc }}=\mathrm{HS}^{-}{ }_{\text {inf }}-\mathrm{HS}^{-}{ }_{\text {eff }}-\mathrm{SO}_{4}{ }^{2-}{ }_{\text {eff }}-\mathrm{S}_{\mathrm{ss}}^{0}
$$

The basic chemical reactions (Eqs. 2, 3) and reactions combining both anabolism (biomass production) and catabolism (energy release) (Eqs. 4, 5) according to Kleerebezem and Mendez (2002) serve as the core for the model. However, these equations assume production of only one sulfur component at specific N/S ratio and does not include temperature impact.

$$
\begin{gathered}
\mathrm{HS}^{-}+1.6 \mathrm{NO}_{3}^{-}+0.6 \mathrm{H}^{+} \rightarrow 0.8 \mathrm{~N}_{2}+\mathrm{SO}_{4}{ }^{2-}+0.8 \mathrm{H}_{2} \mathrm{O} \\
\mathrm{HS}^{-}+0.4 \mathrm{NO}_{3}{ }^{-}+1.4 \mathrm{H}^{+} \rightarrow 0.2 \mathrm{~N}_{2}+\mathrm{S}^{0}+1.2 \mathrm{H}_{2} \mathrm{O} \\
3 \mathrm{HS}^{-}+3.9 \mathrm{NO}_{3}{ }^{-}+0.2 \mathrm{NH}_{4}^{+}+\mathrm{HCO}_{3}^{-+}+1.7 \mathrm{H}^{+} \rightarrow \\
\mathrm{CH}_{1.8} \mathrm{O}_{0.5} \mathrm{~N}_{0.2}+1.95 \mathrm{~N}_{2}+3 \mathrm{SO}_{4}^{2-}+2.3 \mathrm{H}_{2} \mathrm{O} \\
14.5 \mathrm{HS}^{-}+5 \mathrm{NO}_{3}{ }^{-}+0.2 \mathrm{NH}_{4}{ }^{+}+\mathrm{HCO}_{3}^{-}+20.3 \mathrm{H}^{+} \rightarrow \\
\mathrm{CH}_{1.8} \mathrm{O}_{0.5} \mathrm{~N}_{0.2}+2.5 \mathrm{~N}_{2}+14.5 \mathrm{~S}^{0}+17.4 \mathrm{H}_{2} \mathrm{O}
\end{gathered}
$$

The new stoichiometry applied here includes simultaneous $\mathrm{NO}_{3}^{-}$and $\mathrm{HS}^{-}$removal and possibility to produce two sulfur components: $\mathrm{S}^{0}$ (without distinguishing the $\mathrm{S}^{0}$ fractions) and $\mathrm{SO}_{4}{ }^{2-}$ according to Eq. 6.

$$
a \mathrm{NO}_{3}{ }^{-}+b \mathrm{HS}^{-}-\mathrm{S} \rightarrow c \mathrm{~S}^{0}+d \mathrm{SO}_{4}{ }^{2-}+e \mathrm{~N}_{2}
$$

Where $c$ and $d$ depend on feed molar ratio between $a$ and $b(\mathrm{~N} / \mathrm{S}$ ratio) and temperature (T) (Eqs. 7, 8).

$$
\begin{aligned}
& c=f(\mathrm{~N} / \mathrm{S} ; \mathrm{T}) \\
& d=f(\mathrm{~N} / \mathrm{S} ; \mathrm{T})
\end{aligned}
$$

\subsection{Kinetics}

Process kinetics is modeled based on the Monod equation for reaction rates and assuming one general microbial community of sulfide oxidizing bacteria (SOB). The growth of microorganisms is thus described using the Bailey's equation that includes both required substrates (Eq. 9). The biomass concentration is assumed constant in the simulations due to the conditions with high biomass content in the EGSB reactor and low biomass yield of autotrophic denitrification bacteria (Tchobanoglous et al., 2003), implying that reactor biomass changes are insignificant during the experiments used in this study. The growth parameters maximum growth rate $\left(\mu_{\max }\right)$ and halfsaturation constants $\left(\mathrm{K}_{\mathrm{HS}-}, \mathrm{K}_{\mathrm{NO} 3}\right)$ applied are given in Table 2 .

$$
\mu=\mu_{\text {max }} \cdot X_{S O B}\left(\frac{S_{H S^{-}}}{K_{H S^{-}}+S_{H S^{-}}}\right)\left(\frac{S_{N_{3}^{-}}}{K_{N_{3}^{-}}+S_{N O_{3}^{-}}}\right)
$$

Table 2. Growth parameters.

\begin{tabular}{|c|l|l|}
\hline Parameter & Value & \begin{tabular}{l} 
Source \\
\hline$\mu_{\max }$
\end{tabular} \\
\cline { 1 - 3 } & $4.25 \mathrm{~d}^{-1}$ & $\begin{array}{l}\text { (Wang et al., } \\
2010)\end{array}$ \\
\hline$K_{\mathrm{NO}_{3}^{-}}$ & $7.84 \mathrm{mM} \mathrm{NO}_{3}^{-} / \mathrm{L}$ & $\begin{array}{l}(\mathrm{Xu} \text { et al., } \\
2016)\end{array}$ \\
\hline$K_{\mathrm{HS}^{-}}$ & $1.8 \mathrm{mM} \mathrm{S}^{2-} / \mathrm{L}$ & \\
\hline
\end{tabular}

The mathematical model is implemented in the AQUASIM simulation software (Eawag, Switzerland). The established model is calibrated and used to simulate removal of $\mathrm{NO}_{3}^{-}$and $\mathrm{HS}^{-}$. Simulation results are 
compared with the obtained experimental data published in Sposob et al. (2017a, 2017b).

\subsection{Temperature}

Temperature has an impact on bacterial kinetic coefficients like $\mu_{\max }$ and $\mathrm{K}_{\mathrm{S}}$ leading to changes in the treatment efficiency. During the experimental trial the electron donor (HS-S) removal changed from 98 (25 ${ }^{\circ} \mathrm{C}$ ) to $89 \%$ at $10{ }^{\circ} \mathrm{C}$. Temperature also influenced the effluent composition of sulfur components in the experiment modeled here (Figure 1). Electron acceptor $\left(\mathrm{NO}_{3}{ }^{-}\right)$removal was not significantly influenced by temperature as it was completely removed (effluent $\mathrm{NO}_{3}^{-}$was detected only three times during 120 days temperature-trial).

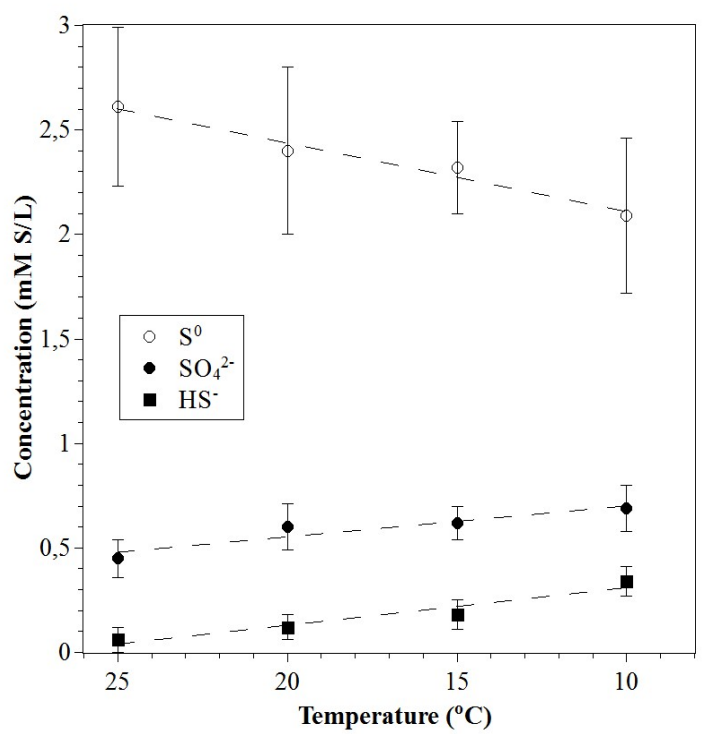

Figure 1. Average concentration of sulfur components at 25-10 ${ }^{\circ} \mathrm{C}$ and $\mathrm{N} / \mathrm{S}=0.35$ (Sposob et al., 2017a).

With decreasing temperature and invariable feeding pattern, the share of $\mathrm{S}^{0}$ decreased while $\mathrm{SO}_{4}{ }^{2-}$ together with HS $^{-}$increased. Performed free Gibbs energy calculations $\left(\Delta \mathrm{G}^{0^{\prime}}\right)$ revealed that the reaction energy at the different temperatures remained nearly constant due to this shift in products formation from $\mathrm{S}^{0}$ to $\mathrm{SO}_{4}{ }^{2-}$ (Sposob et al., 2017a). The reaction energy maintained at invariable feeding conditions is dependent on the relationships given in Eqs. 10 and 11. The culture evidently preferred to use more $\mathrm{NO}_{3}{ }^{-}$per mole of $\mathrm{HS}^{-}$at lower temperatures. Whether this is due to a shift in microbial community or a metabolic shift within cells is currently under investigation. Until such information is available an empirical temperature effect is implemented in the model by temperature dependent stoichiometric coefficients (Table 3) based on the experimental results given in Figure 1.

$$
\begin{gathered}
\text { Reaction energy }=\text { oxidation to } \mathrm{S}^{0}+ \\
\text { oxidation to } \mathrm{SO}_{4}^{2-} \\
\text { Reaction energy } \approx \text { constant }
\end{gathered}
$$

Table 3. Temperature coefficient for stoichiometric parameters calculated based on the experimental trial.

\begin{tabular}{|l|l|l|}
\hline Temperature & $T_{\text {sulfur }}$ & $T_{\text {sulfate }}$ \\
\hline 25 & 0.84 & 0.14 \\
\hline 20 & 0.77 & 0.19 \\
\hline 15 & 0.74 & 0.2 \\
\hline 10 & 0.67 & 0.22 \\
\hline
\end{tabular}

\section{$2.5 \mathrm{~N} / \mathrm{S}$ ratio}

Changes in N/S ratio have been reported as a way to control the level of $\mathrm{HS}^{-}$oxidation (Cai et al., 2008). However, the results at different ratios at $10{ }^{\circ} \mathrm{C}$ show a significant offset from the theoretical values (Figure 2). The highest offset was obtained for $\mathrm{S}^{0}$. Experimental results equaled the theoretical values only at $\mathrm{N} / \mathrm{S}=1.30$. A more detailed description of $\mathrm{N} / \mathrm{S}$ ratio impact at psychrophilic conditions $\left(10^{\circ} \mathrm{C}\right)$ is given in Sposob et al. (2017b). Modeling effects of N/S ratios in Eq. 7 and 8 based on these observations is implemented through correction coefficients given in Table 4.

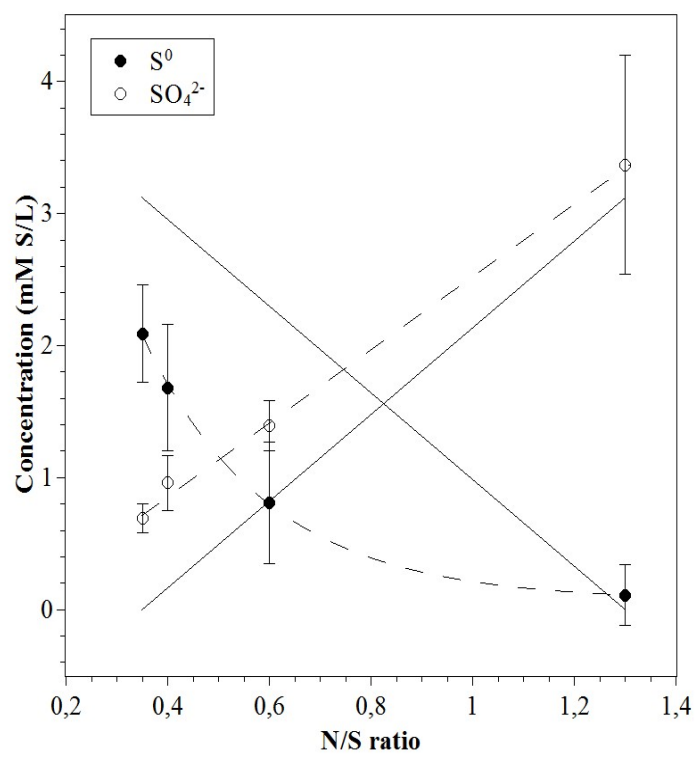

Figure 2. Average concentration of sulfur components at different $\mathrm{N} / \mathrm{S}$ ratios at $10{ }^{\circ} \mathrm{C}$. Whole lines are theoretical values based on Eqs. 4, 5 while dotted line connects the given experimental values.

Table 4. N/S ratio coefficient for stoichiometric parameters calculated based on the experimental trial.

\begin{tabular}{|l|l|l|}
\hline$N /$ S ratio & $N / S_{\text {sulfur }}$ & $N / S_{\text {sulfate }}$ \\
\hline 0.35 & 1 & 1 \\
\hline 0.40 & 0.81 & 1.41 \\
\hline 0.60 & 0.48 & 2.05 \\
\hline 1.30 & 0.06 & 4.36 \\
\hline
\end{tabular}




\section{Results and Discussion}

Simulations, with the calculated coefficients (Table 3) of products distribution $\left(\mathrm{S}^{0}\right.$ and $\left.\mathrm{SO}_{4}{ }^{2-}\right)$ with different temperatures and constant feed N/S $=0.35$ behaves similar to the experimental results (Figure 3). The implemented model with the temperature coefficients (Table 3) simulates the pseudo-steady state relative amounts of effluent $\mathrm{S}^{0}$ and $\mathrm{SO}_{4}{ }^{2-}$. This may seem obvious since the coefficients are calculated based on average values for each temperature case of the same data set. The model, however, also simulates the transitions in relative amounts of products occurring following each $5{ }^{\circ} \mathrm{C}$ temperature drop (the initial part of each of the three last panels in Figure 3) quite accurately. The model significantly improved predictions at $\mathrm{N} / \mathrm{S}=0.35$ compared to the equations (Eqs. 3, 5) that predict $\mathrm{S}^{0}$ production only and no temperature effect.

Increasing the model complexity, including diversification of microbes and/or the implementation of energy terms, can further improve the model for better prediction of $\mathrm{HS}^{-}$removal and products distribution for a wider range of conditions. However, further experimental investigations are required to implement such.

Experimental data and predictions based on Kleerebezem and Mendez (2002) equations (Eqs. 4, 5) are compared in Figure 2 regarding N/S ratio effects on products distribution. The observed offset between experimental and theoretical values could be partly due to the oxidation of earlier accumulated $\mathrm{S}^{0}$ (reaction 3 in the schematic presentation of the studied process in Figure 4), but this is not explicitly included in the mathematical model. The reaction energy from $\mathrm{HS}^{-}$ oxidation is increasing with increased amount of $\mathrm{NO}_{3}{ }^{-}$ supplied. Probably both of these energy related phenomena influence the products distribution but insufficient results are yet available to distinguish these. Thus, further model refinement to include both hypothesized energy reactions separately is not attempted and the cumulative effect observed experimentally are covered by the coefficients given in Tables 3 and 4 and simulated (Figure 5).
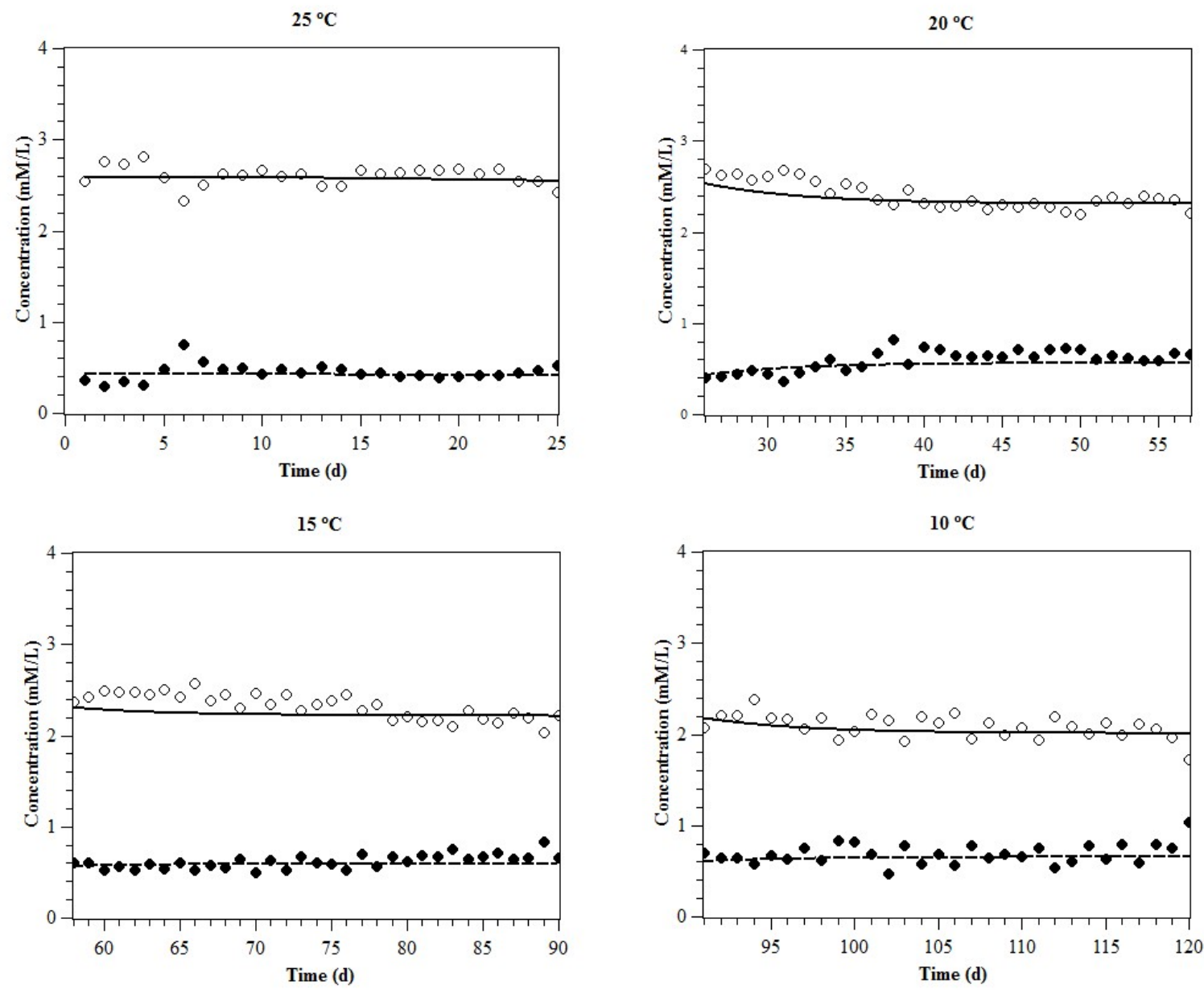

Figure 3. Model simulation results in comparison to experimental results at different temperatures. Solid and dash line represent simulated results for $\mathrm{S}^{0}$ and $\mathrm{SO}_{4}{ }^{2-}$, respectively. Scatter points represent experimental results for $\mathrm{S}^{0}(0)$ and $\mathrm{SO}_{4}{ }^{2-}$

$(\bullet)$. 


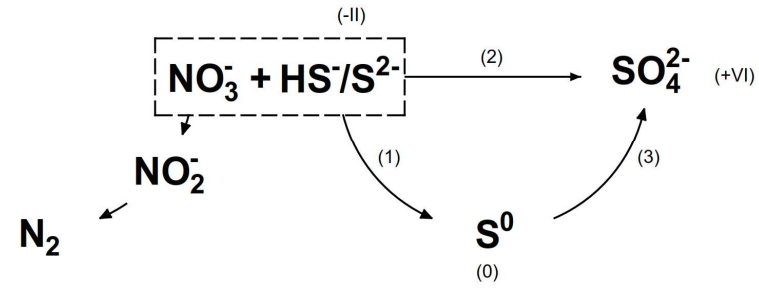

Figure 4. The scheme of autotrophic denitrification with $\mathrm{HS}^{-}$as electron donor.

The simulations with the applied coefficients related to N/S ratio (Table 4) significantly improved predictions compared to those in Figure 2, except for $\mathrm{N} / \mathrm{S}=1.30$, where simple stoichiometric calculations matched the experimental values best. The poor simulation of experimental results at $\mathrm{N} / \mathrm{S}=1.30$ is assumed to be due to the fact that reaction 3 in Figure 4 is not explicitly accounted for in the model and that this reaction is especially important at this stage. This is due to the experimental scenario which at the beginning was focused on $\mathrm{S}^{0}$ production leading to its accumulation, as energy storage for the microorganisms. This $\mathrm{S}^{0}$ energy reserve in the reactor was oxidized to $\mathrm{SO}_{4}{ }^{2-}$ and is especially visible at $\mathrm{N} / \mathrm{S}=1.30$. This implies that a more refined future model of simultaneous biological removal of $\mathrm{HS}^{-}$and $\mathrm{NO}_{3}^{-}$needs to consider the effect of $\mathrm{S}^{0}$ accumulation and its possible oxidation (Figure 4) as occurred here under N/S ratio effects trial.

The energy related aspects discussed here are not included in the previously published models since these are based mainly on batch experiments and high N/S ratio situations. The observed phenomena probably occur only in cases when the N/S ratio is in or close to the range investigated here and are most observable when increasing from low $\left(\mathrm{S}^{0}\right.$ production related) to high $\mathrm{N} / \mathrm{S}$ ratios $\left(\mathrm{SO}_{4}{ }^{2-}\right.$ production related). It can therefore be useful to develop the model further to better account for accumulation and consumption of $\mathrm{S}^{0}$. Some relevant information is available, such as: kinetics for $\mathrm{S}^{0}$ leaching and usage as electron donor is available (Franzmann et al., 2005; Gourdon and Funtowicz, 1998; Koenig and Liu, 2001). Models including similar accumulation phenomena related to energy storage are developed, i.e. ASM2d where the accumulation and
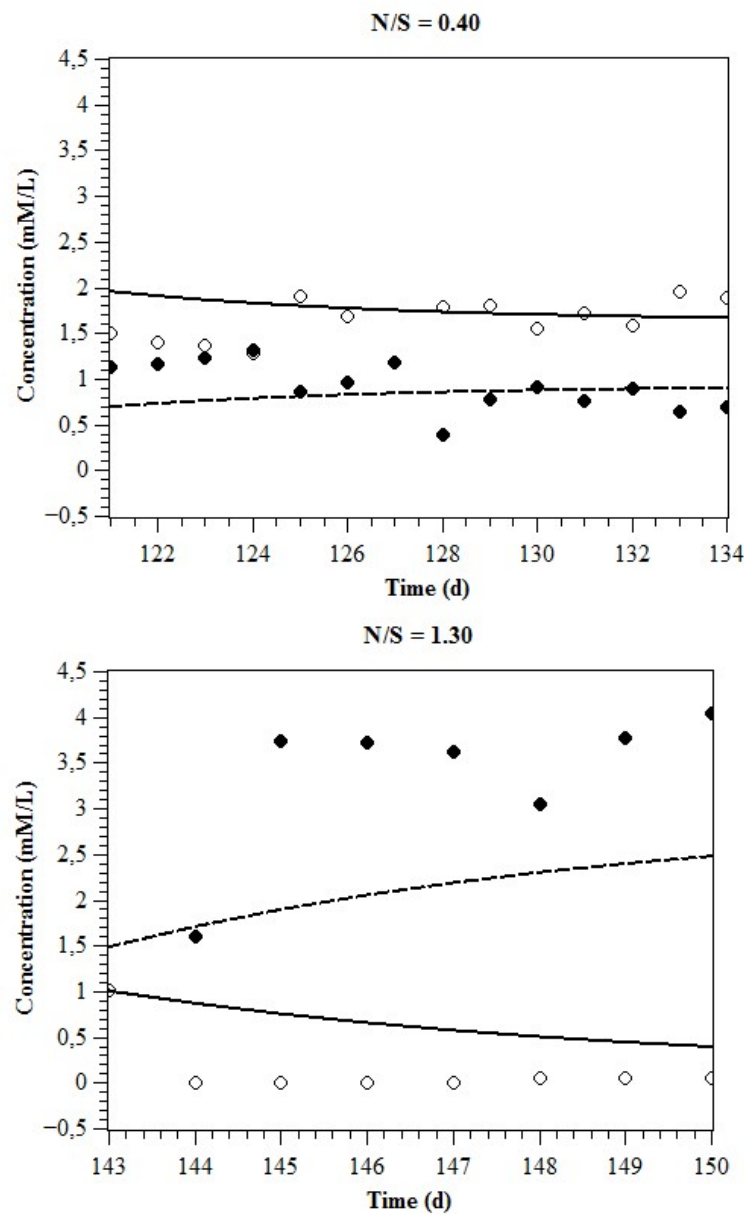

Figure 5. Model simulation results in comparison to experimental results at different N/S ratios at $10{ }^{\circ} \mathrm{C}$. Solid and dash line represent simulated results for $\mathrm{S}^{0}$ and $\mathrm{SO}_{4}{ }^{2-}$ respectively. Scatter points represent experimental results for $\mathrm{S}^{0}(\circ)$ and $\mathrm{SO}_{4}^{2-}(\bullet)$ 
consumption of polyhydroxybutyrate (PHB) and polyphosphate (PP) are taken into account (Henze et al., 1999). However, the factors triggering the oxidation of accumulated $\mathrm{S}^{0}$ are not clear. It has been reported that the oxidation can only occur when the source of reduced sulfur compounds is depleted (Schedel and Trüper, 1980), but oxidation of accumulated $\mathrm{S}^{0}$ can obviously occur (e.g. Figure 2) and be influenced by both temperature and N/S ratio changes when $\mathrm{HS}^{-}$(sulfur reduced compound) is available (Sposob et al., 2017b, 2016). The observation that $S^{0}$ leaching increases with temperature (Franzmann et al., 2005) should also be accounted for in the further model development.

\section{Conclusions}

The presented model can serve as a prediction tool for autotrophic denitrification with $\mathrm{HS}^{-}$as supplied electron donor, to account for effects of temperature and feed $\mathrm{N} / \mathrm{S}$ ratio.

The model was able to simulate sulfur compound products distribution at different temperatures, more accurately at low than higher N/S ratios (N/S range 0.35 to 1.30 ).

The phenomena of $\mathrm{S}^{0}$ production included in the mathematical model does not take into account its accumulation and release (as $\mathrm{SO}_{4}{ }^{2-}$ ). Thus, adequate prediction of products distribution caused by $\mathrm{N} / \mathrm{S}$ ratio step increases (leading to higher concentration of sulfur components in the effluent than fed into the reactor) was not obtained. Therefore, a conceptual model is proposed to account for biological accumulation and release of $\mathrm{S}^{0}$. Further investigations on $\mathrm{N} / \mathrm{S}$ ratio effects on $\mathrm{S}^{0}$ accumulation and release can yield a more refined model of simultaneous biological removal of $\mathrm{HS}^{-}$and $\mathrm{NO}_{3}{ }^{-}$.

\section{Acknowledgements}

The authors would like to thank YARA AS International and The Research Council of Norway for support of this research.

\section{References}

Cai, J., Zheng, P., and Mahmood, Q. Effect of sulfide to nitrate ratios on the simultaneous anaerobic sulfide and nitrate removal. Bioresource Technology, 99(13):5520-5527, 2008.

Cai, J., Zheng, P., and Mahmood, Q. Influence of transient $\mathrm{pH}$ and substrate shocks on simultaneous anaerobic sulfide and nitrate removal. Journal of Hazardous Materials, 174(1-3):162-166, 2010.

Chen, Y., Cheng, J. J., and Creamer, K. S. Inhibition of anaerobic digestion process: A review. Bioresource Technology, 99(10):4044-4064, 2008.

Di Capua, F., Milone, I., Lakaniemi, A. M., Lens, P. N.
L., and Esposito, G. High-rate autotrophic denitrification in a fluidized-bed reactor at psychrophilic temperatures. Chemical Engineering Journal, 313:591-598, 2017.

Franzmann, P. D., Haddad, C. M., Hawkes, R. B., Robertson, W. J., and Plumb, J. J. Effects of temperature on the rates of iron and sulfur oxidation by selected bioleaching Bacteria and Archaea: Application of the Ratkowsky equation. In Minerals Engineering 18:1304-1314, 2005.

Gourdon, R., and Funtowicz, N. (1998). Kinetic model of elemental sulfur oxidation by Thiobacillus thiooxidans in batch slurry reactors: Effects of surface characteristics and suspended solid concentration. Bioprocess Engineering, 18(4):241-249, 1998.

Guo, Q., Hu, H. Y., Shi, Z. J., Yang, C. C., Li, P., Huang, M., Ni, W. M., Shi, M. N., and Jin, R. C. Towards simultaneously removing nitrogen and sulfur by a novel process: Anammox and autotrophic desulfurization-denitrification (AADD). Chemical Engineering Journal, 297, 207-216, 2016.

Henze, M., Gujer, W., Mino, T., Matsuo, T., Wentzel, M. C., Marais, G. V. R., and Van Loosdrecht, M. C. M. (1999). Activated Sludge Model No.2d, ASM2d. Water Science and Technology 39:165$182,1999$.

Huang, C., Li, Z., Chen, F., Liu, Q., Zhao, Y., Gao, L., Chen, C., Zhou, J., and Wang, A. Efficient regulation of elemental sulfur recovery through optimizing working height of upflow anaerobic sludge blanket reactor during denitrifying sulfide removal process. Bioresource Technology, 200:1019-1023, 2016.

Jin, R. C., Yang, G. F., Zhang, Q. Q., Ma, C., Yu, J. J., and Xing, B. S. The effect of sulfide inhibition on the ANAMMOX process. Water Research, 47(3):1459-1469, 2013.

Joye, S. B., and Hollibaugh, J. T. Influence of sulfide inhibition of nitrification on nitrogen regeneration in sediments. Science, 270(5236):623-625, 1995.

Kleerebezem, R., and Mendez, R. Autotrophic denitrification for combined hydrogen sulfide removal from biogas and post-denitrification. Water Science and Technology, 45(10):349-356, 2002.

Koenig, A., and Liu, L. H. Kinetic model of autotrophic denitrification in sulphur packed-bed reactors. Water Research, 35(8):1969-1978, 2001.

Ma, H., Cheng, X., Li, G., Chen, S., Quan, Z., Zhao, S., and Niu, L. The influence of hydrogen sulfide on corrosion of iron under different conditions. Corrosion Science, 42(10):1669-1683, 2000.

Mahmood, Q., Zheng, P., Cai, J., Wu, D., Hu, B., and 
$\mathrm{Li}$, J. Anoxic sulfide biooxidation using nitrite as electron acceptor. Journal of Hazardous Materials, 147(1-2):249-256, 2007.

Montalvo, S., Huiliñir, C., Gálvez, D., Roca, N., and Guerrero, L. Autotrophic denitrification with sulfide as electron donor: Effect of zeolite, organic matter and temperature in batch and continuous UASB reactors. International Biodeterioration and Biodegradation, 108:158165, 2016.

Pikaar, I., Rozendal, R. A., Yuan, Z., Keller, J., and Rabaey, K. (2011). Electrochemical sulfide removal from synthetic and real domestic wastewater at high current densities. Water Research, 45(6):2281-2289, 2011.

Reiffenstein, R. J., Hulbert, W. C., and Roth, S. H. Toxicology of hydrogen sulfide. Annual Review of Pharmacology and Toxicology, 32(1):109134, 1992.

Reyes-Avila, J., Razo-Flores, E., and Gomez, J. Simultaneous biological removal of nitrogen, carbon and sulfur by denitrification. Water Research, 38(14-15):3313-3321, 2004.

Schedel, M., and Trüper, H. G. Anaerobic oxidation of thiosulfate and elemental sulfur in Thiobacillus denitrificans. Archives of Microbiology, 124(23):205-210, 1980

Sposob, M., Bakke, R., and Dinamarca, C. Effects of $\mathrm{N} / \mathrm{S}$ molar ratio on products formation in psychrophilic autotrophic biological removal of sulfide. Water, 9(7):476, 2017 a.

Sposob, M., Bakke, R., and Dinamarca, C. Metabolic divergence in simultaneous biological removal of nitrate and sulfide for elemental sulfur production under temperature stress. Bioresource Technology, 233:209-215, 2017b.

Sposob, M., Dinamarca, C., and Bakke, R. Short-term temperature impact on simultaneous biological nitrogen-sulphur treatment in EGSB reactor. Water Science and Technology, 74(7):16101618, 2016.

Tan, W., Huang, C., Chen, C., Liang, B., and Wang, A. Bioaugmentation of activated sludge with elemental sulfur producing strain Thiopseudomonas denitrificans X2 against nitrate shock load. Bioresource Technology, 220:647650, 2016.

Tchobanoglous, G., Burton, F. L., and Stensel, H. D. (2003). Wastewater Engineering: Treatment and Reuse (Fourth Edition). Wastewater Engineering, Treatment, Disposal and Reuse, 2003.

Wang, A., Liu, C., Han, H., Ren, N., and Lee, D. J. Modeling denitrifying sulfide removal process using artificial neural networks. Journal of Hazardous Materials, 168(2-3):1274-1279, 2009.

Wang, A., Liu, C., Ren, N., Han, H., and Lee, D.
Simultaneous removal of sulfide, nitrate and acetate: Kinetic modeling. Journal of Hazardous Materials, 178(1-3):35-41, 2010.

Wang, X., Zhang, Y., Zhou, J., Zhang, T., and Chen, $M$. Regeneration of elemental sulfur in a simultaneous sulfide and nitrate removal reactor under different dissolved oxygen conditions. Bioresource Technology, 182:75-81, 2015.

$\mathrm{Xu}, \mathrm{G} ., \mathrm{Yin}, \mathrm{F} ., \mathrm{Chen}, \mathrm{S} ., \mathrm{Xu}, \mathrm{Y}$., and Yu, H. Q. Mathematical modeling of autotrophic denitrification (AD) process with sulphide as electron donor. Water Research, 91:225-234, 2016.

Xu, X., Chen, C., Wang, A., Guo, W., Zhou, X., Lee, D. J., Ren, N., and Chang, J. S. Simultaneous removal of sulfide, nitrate and acetate under denitrifying sulfide removal condition: Modeling and experimental validation. Journal of Hazardous Materials, 264:16-24, 2014. 